\title{
A Large Placental Chorioangioma without an Adverse Perinatal Effect
}

\author{
Serpil Aydogmus ${ }^{1}$, Zeynep Seyhanli ${ }^{2}$, Serenat Eris ${ }^{3}$, Hüseyin Aydogmus ${ }^{4}$, \\ Seyran Ceri Yiğit ${ }^{5}$ and Sefa Kelekci ${ }^{6}$ \\ 1,2,3,4,6 Izmir Katip Celebi University Ataturk Training and Research Hospital, Department \\ of Obstetrics and Gynecology, Izmır, Turkey \\ ${ }^{5}$ Izmir Katip Celebi University Ataturk Training and Research Hospital, Department \\ of Pathology, Izmır,Turkey
}

Correspondence should be addressed to: Serenat Eris; serenateris@hotmail.com

Received date: 25 Mai 2014; Accepted date: 14 July 2014; Published date: 19 August 2015

Academic Editor: El Said Abdel-Hady

Copyright (C) 2015. Serpil Aydogmus, Zeynep Seyhanli, Serenat Eris, Hüseyin Aydogmus, Seyran Ceri Yiğit and Sefa Kelekci . Distributed under Creative Commons CC-BY 4.0

\begin{abstract}
Chorioangiomas are the most common benign tumors of placenta with reported prevalence of approximately $0.5 \%-1 \%$. Large tumors are rare but those exceeding $5 \mathrm{~cm}$ in diameter may be associated with adverse effects on both mother and fetus. The larger the size of the tumor the more is the chance of developing complications. However, it is not necessary that complications would always ensue. Here, we present a case with a large asymptomatic placental chorioangioma that was found incidentally at term and led to a successful outcome. Despite the large size, it was not associated with the maternal or fetal complications expected with a chorioangioma of that size.
\end{abstract}

Keywords: placental chorangioma, placental tumor, fetal complication

\section{Introduction}

Chorioangiomas are the most common benign tumors of placenta with reported prevalence of approximately $0.5 \%-1 \%$ (1). Large tumors are rare but those exceeding $5 \mathrm{~cm}$ in diameter may be associated with adverse effects on both mother and fetus which include intrauterine growth restriction, fetal anemia, thrombocytopenia, congestive heart failure, polyhydramnios, preterm labor, preeclampsia and sudden infant death (27). The larger the size of the tumor the more is the chance of developing complications. However, it is not necessary that complications would always ensue. Here we present a case with a large asymptomatic placental chorioangioma that was found incidentally at term and led to a successful outcome. Despite the large size, it was not associated with the

Cite this Article as: Serpil Aydogmus, Zeynep Seyhanli, Serenat Eris, Hüseyin Aydogmus, Seyran Ceri Yiğit and Sefa Kelekci (2015), "A Large Placental Chorioangioma Without An Adverse Perinatal Effect" International Journal of Case Reports in Medicine, Vol. 2015 (2015), Article ID 613512, 
maternal or fetal complications expected with a chorioangioma of that size.

\section{Case Presentation}

A 20 year-old primigravida, who did not have routine antenatal follow-up, was admitted to our emergency department with rupture of membranes at 39 weeks of pregnancy. She underwent a scan which showed a normally growing fetus with no gross fetal anomalies and normal liquor volume but a well-defined hypoechoic area $7 * 6 \mathrm{cms}$ near the lower edge of the placenta. Colour Doppler examination showed vasculature suggestive of chorioangioma. She underwent emergency cesarean section for cephalopelvic disproportion in labour. A female baby with normal Apgar score and birth weight of 3.6 kilograms was delivered. Neonatal examination and follow-up were normal. Placenta was delivered by controlled cord traction. Macroscopically, the placenta was 20X18X4 cms and weighed 726 grams. There was a large polypoid well-circumscribed lesion on the placenta measuring 7X7X6 cms ( Figure: I ,II). Then, the placenta was sent for histopathology. Microscopic examination revealed benign mass composed of closely packed vascular spaces lined by endothelial cells and scanty loose intervening stroma. Pathological analysis confirmed the diagnosis of placental chorioangioma. The patient was discharged in good condition (the mother and the baby) 24 hours after surgery.

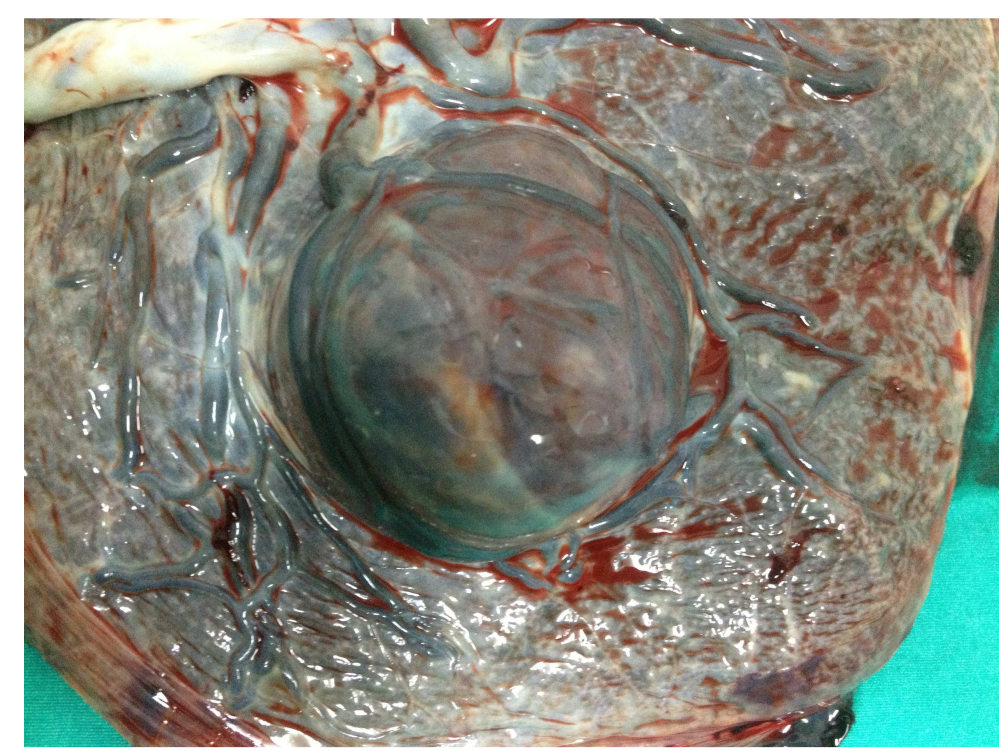

Figure 1: A large placental chorioangioma 


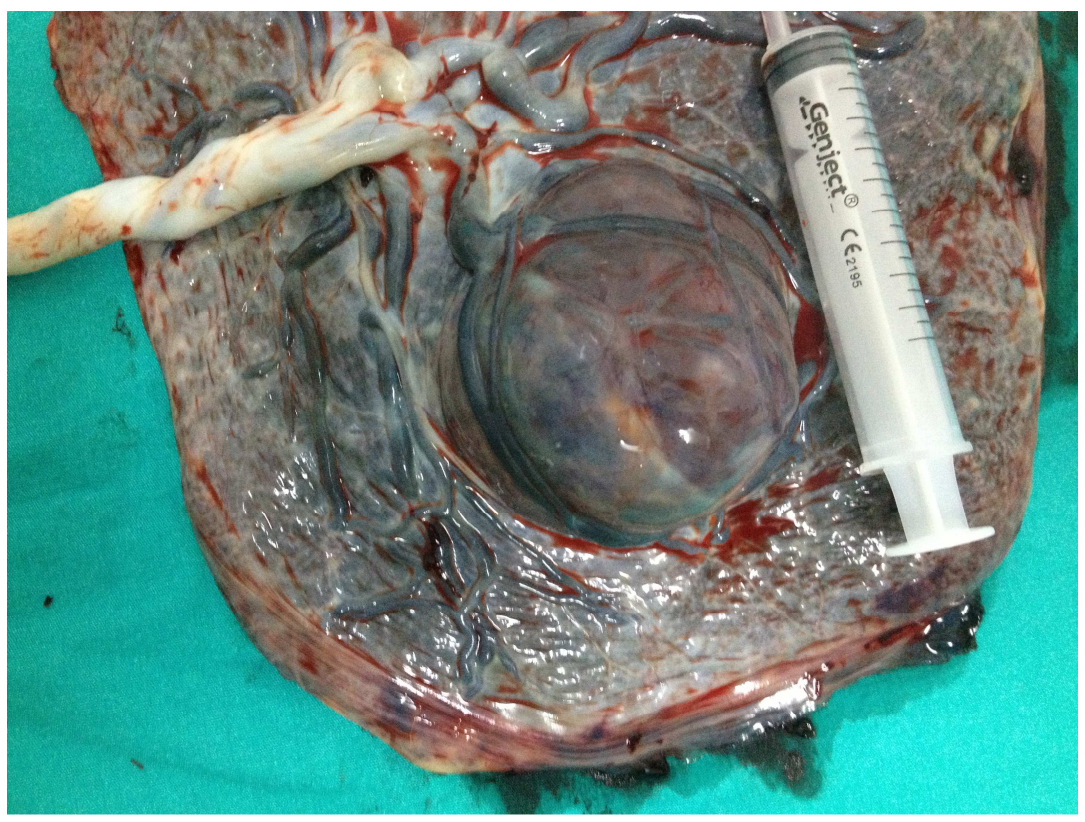

Figure 2: A large vascular tumor suggestive of chorioangioma after delivery

\section{Discussion}

Chorioangioma of the placenta is a relatively rare entity which most often goes unnoticed. It was first described by Clarke in 1798. Chorioangiomas range from microscopic lesions to large masses. Most chorioangiomas are small and are found incidentally at screening obstetric examinations. Large chorioangiomas (> 4-5 $\mathrm{cm})$ are rare and have been reported to occur at a rate of 1: 3500 to 1: 9000 births (1).

Recognized maternal risk factors associated with chorioangioma are advanced maternal age, hypertension and diabetes mellitus. They are more common in multiple pregnancy and female babies (2).

Chorioangioma consists of a benign angioma arising from chorionic tissue. Three histological patterns of chorioangiomas have been described by Marchetti: angiomatous (capillary), cellular, and degenerative, with angiomatous as the most common type (3). There is no malignant potantial (4-6).

Large chorioangiomas may cause serious complications and carry a risk of fetal and maternal morbidity (5). These associated complications are polyhydramnios, preterm labor, fetal hemolytic anemia, fetal thrombocytopenia, fetal cardiomegaly, intrauterine growth restriction, toxemia, placental abruption, preeclampsia, and congenital abnormalities (6-7). Although the underlying pathophysiology has not been fully elucidated, a prominent role for arteriovenous shunting and sequestration of red blood cells and platelets by the tumor has been postulated $(3,6)$. Although a large size of the tumor is indicative of a higher probability for arteriovenous shunting, in some cases, like ours, arteriovenous shunts do not develop. It could be an explanation of how our case did not develop complications despite the large size.

Different investigation modalities have been used for the early diagnosis and management of placental tumors. Grayscale findings are well-defined hypo- or hiperechogenic mass different from the rest of placenta and tumor protrudes into amniotic cavity near umbilical cord insertion (8). On Colour Doppler, feeding vessel usually has the same pulsatile flow as that of umbilical artery but may have arteriovenous shunt causing low resistance flow (9). Strong suspicion of chorioangioma on Doppler ultrasound rules out the need for additional expensive 
imaging modalities like magnetic resonance investigation (MRI). Unfortunately, we could not do gray-scale or Doppler in earlier trimesters because our patient did not come on regular followup. Chorioangioma is often confused with placental teratoma, placental hematoma (intraplacental or subchorionic), partial hydatidiform mole, degenerated myoma, and metastases (8).
Chorioangioma is usually treated with expectant management, as the majority of tumors are asymptomatic. There are several modalities of treatment for complications of chorioangioma such as serial fetal transfusions, fetoscopic laser coagulation of vessels supplying the tumor, chemosclerosis with absolute alcohol, and endoscopic surgical devascularization $(10,11)$.

Table 1: Successful Pregnancy outcomes with large placental chorioangiomas in literature

\begin{tabular}{|l|c|c|c|c|}
\hline $\begin{array}{l}\text { Authors } \\
\text { (reference) }\end{array}$ & Case Number & $\begin{array}{l}\text { Gestational age } \\
\text { at diagnosis } \\
\text { (weak) }\end{array}$ & $\begin{array}{l}\text { Chorioangioma } \\
\text { size (mm) }\end{array}$ & $\begin{array}{l}\text { Perinatal } \\
\text { Outcome }\end{array}$ \\
\hline $\begin{array}{l}\text { Sepulveda et. } \\
\text { al.(5) }\end{array}$ & 4 & $32,24,21,35$ & $\begin{array}{l}73 * 71,43^{*} 42 \\
68 * 41,45^{*} 41\end{array}$ & $\begin{array}{c}\text { Term Delivery } \\
\text { Healthy } \\
\text { neonates }\end{array}$ \\
\hline $\begin{array}{l}\text { Ruman } \\
\text { et.al.(12) }\end{array}$ & 1 & 26 & $70 * 60$ & $\begin{array}{c}\text { Term Delivery } \\
\text { Healthy neonate }\end{array}$ \\
\hline $\begin{array}{l}\text { Acharya } \\
\text { et.al.(13) }\end{array}$ & 1 & $17+2$ & $103 * 107$ & $\begin{array}{l}\text { Term Delivery } \\
\text { Healthy neonate }\end{array}$ \\
\hline $\begin{array}{l}\text { Ulkumen } \\
\text { et.al.(14) }\end{array}$ & 2 & 36,26 & $70 * 70,50 * 40$ & $\begin{array}{c}\text { Term Delivery } \\
\text { Healthy } \\
\text { neonates }\end{array}$ \\
\hline
\end{tabular}

\section{Conclusion}

We presented a case with an asymptomatic placental chorioangioma despite its large size. Large chorioangiomas may cause serious complications so it is important to acchieve prenatal diagnosis. A routine antenatal screening ultrasound scan should include a screen of the placental composition not just its location. After diagnosis close follow-up of pregnancy by serial ultrasound and Doppler studies is recommended to detect and manage complications. However it, is not necessary that complications would always ensue, so large chorioangiomas can still be managed conservatively with succesful outcome by close monitoring.

\section{Declaration}

We have no financial or commercial conflicts of interest.

\section{References}

1.Benirschke K, Kaufman P.Pathology of the Human Placenta: BenignTumors. SpringerVerlag: New York, NY, 1995; 709-718.

2.Kodandapani S, Shreshta A, Ramkumar V, Rao L. Chorioangioma of placenta: a rare placental cause for adverse fetal outcome. Case Rep Obstet Gynecol. 2012;2012:913878.

3.A. A. Marchetti. A consideration of certain types of benign tumors of the placenta. Surgery, Gynecology\&Obstetrics, 1939;68: 733-743.

4.Qichang W1, Wenbo W, Liangkai Z, Hui K, Xiaoqin H, Li S, Yasong X. Pregnancy with concomitant chorioangioma and placental mesenchymal dysplasia: a rare placental abnormality. Case Rep Obstet Gynecol. 2013;2013:591956.

5.Sepulveda W, Alcalde JL, Schnapp C, Bravo M. Perinatal outcome after prenatal 
diagnosis of placental chorioangioma. Obstet Gynecol 2003; 102:1028.

6.Napolitano R, Maruotti G, Mazzarelli L, Quaglia F, Tessitore GP. Prenatal diagnosis of placental chorioangioma: our experience. Minerva Ginecol 2005; 57: 649 - 654.

7.Zalel Y, Weisz B, Ronni G, Schiff E, Shalmon B, Achiron R. Chorioangiomas of the placenta: sono-graphic and Doppler flow characteristics. J Ultra- sound Med 2002; 21(8): 909 -913.

8.Harris RD, Barth RA. Sonography of the gravid uterus and placenta: current concepts. AJR Am J Roentgenol 1993; 160(3): 455- 465.

9.Sepulveda W, Aviles G, Carstens E, Corral E, Perez N. Prenatal diagnosis of solid placental masses: the value of color flow imaging. Ultrasound in Obstetrics and Gynecol 2000; 16: 554-558

10.Quintero RA, Reich H, Romero R, Johnson MP, Goncalves L, Evans MI. In utero endoscopic devascularization of a large chorioangioma. Ultrasound Obstet Gynecol 1996; 8(1): 48 - 52.

11. Al Wattar BH, Hillman SC, Marton T, Foster K, Kilby MD. Placenta chorioangioma: a rare case and systematic review of literature. J Matern Fetal Neonatal Med. 2014 Jul;27(10):1055-63.

12. Ruman U, Chowdhury TS, Nessa M. Placental Chorioangioma: A Case Report. BIRDEM Medical Journal. 2012 Jul; 2(2):113-15.

13. Acharya S, Pringle S. A Case of Placental Chorioangioma with the review of literature. The Internet Journal of Gynaecology and Obstetrics. 2005;5(1).

14. Artunc Ulkumen B1, Pala HG, Nese N, Baytur Y. Prenatal diagnosis and fetomaternal outcomes of two cases with placental chorioangioma. Case Rep Obstet Gynecol. 2013;2013:926743. 